\title{
Model characteristics of sportsmen' preparedness in kettlebell lifting
}

Authors' Contribution:
A Study Design
B Data Collection
C Statistical Analysis
D Data Interpretation
E Manuscript Preparation
F Literature Search
G Funds Collection

G Funds Collection

\section{abstract}

Background:

Material and methods:

Results:

Key words:

Conclusions: The application of the results obtained allows comparing the individual data of a particular sportsman with

\author{
Kostiantyn Prontenko1 ADE, Grygoriy Griban ${ }^{2}$ BCF, Tetiana Plachynda ${ }^{3}$ BG, \\ Ivan Mychka ${ }^{\mathrm{FG}}$, Oksana Khurtenko ${ }^{4}$ AF, Bogdan Semeniv ${ }^{5 \mathrm{DE}}$, Oleksandr Gnydiuk ${ }^{6}$ AG, \\ Vadym Muzhychok7 CE, Mykola Puzdymir8 DF
}

${ }^{1}$ Department of Physical Education, Special Physical Training and Sport,

S. P. Koroliov Zhytomyr Military Institute, Zhytomyr, Ukraine

${ }^{2}$ Department of Physical Education and Sport Improvement, Zhytomyr Ivan Franko State University, Zhytomyr, Ukraine

${ }^{3}$ Department of Professional Pedagogics and Social Humanities, Flight Academy of National Aviation University, Kropyvnytskyi, Ukraine

${ }^{4}$ Department of Theory and Methods of Physical Education,

Vinnytsia Mykhailo Kotsiubynskyi State Pedagogical University, Vinnytsia, Ukraine

${ }^{5}$ Department of Physical Education, Sports and Health, Stepan Gzhytskyi

National University of Veterinary Medicine and Biotechnologies, Lviv, Ukraine

${ }^{6}$ Department of Physical Training and Personal Security, Bohdan Khmelnytskyi National Academy of the State Border Guard Service of Ukraine, Khmelnytskyi, Ukraine

${ }^{7}$ Department of Physical Education, Vinnytsia Mykhailo Kotsiubynskyi State Pedagogical University, Vinnytsia, Ukraine

${ }^{8}$ Department of Physical Education and Sport, Vinnytsia Institute of Trade and Economics of Kyiv National University of Trade and Economics, Vinnytsia, Ukraine

The model characteristics of preparedness of sportsmen specialized in kettlebell lifting are grounded in the article. The indicators of physical preparedness, functional abilities and the main technical characteristics of kettlebell lifters of different qualification were examined.

Three groups were formed: group No. 1 - kettlebell lifters of a low qualification (the 3rd and the 2nd grades, $\mathrm{N}=34$ ); group No. 2 - kettlebell lifters who have the 1st grade and Candidate Master of Sports, $\mathrm{N}=27$; group No. 3 - sportsmen of a high qualification (Masters of Sports, $\mathrm{N}=16$ ). The methods of investigation: theoretical analysis and generalization of scientific literature, testing, biomedical methods, video computer and biomechanical analysis, methods of mathematical statistics.

It is determined that meaningful components of physical preparedness in kettlebell lifting are endurance, flexibility, leg and back muscles strength; of functional preparedness - functional abilities of the cardiovascular and respiratory systems; of technical preparedness - duration of the static phases and angular characteristics of competitive exercises. the model characteristics of highly-qualified sportsmen to estimate the advantages and disadvantages of his preparedness in order to plan the training process.

\section{article details}

Article statistics: Word count: 4,519; Tables: 4; Figures: 0; References: 28

Received: April 2020; Accepted: July 2020; Published: September 2020

Full-text PDF:

http://www.balticsportscience.com

Copyright @ Gdansk University of Physical Education and Sport, Poland

Indexation: Celdes, Clarivate Analytics Emerging Sources Citation Index (ESCI), CNKI Scholar (China National Knowledge Infrastructure), CNPIEC, De Gruyter - IBR (International Bibliography of Reviews of Scholarly Literature in the Humanities and Social Sciences), De Gruyter - IBZ (International Bibliography of Periodical Literature in the Humanities and Social Sciences), DOAJ, EBSCO - Central \& Eastern European Academic Source, EBSCO - SPORTDiscus, EBSCO Discovery Service, Google Scholar, Index Copernicus, J-Gate, Naviga (Softweco, Primo Central (ExLibris), ProQuest - Family Health, ProQuest - Health \& Medical Complete, ProQuest - Illustrata: Health Sciences, ProQuest - Nursing \& Allied Health Source, Summon (Serials Solutions/ProQuest, TDOne (TDNet), Ulrich's Periodicals Directory/ulrichsweb, WorldCat (OCLC)

Funding: This research received no specific grant from any funding agency in the public, commercial, or not-for-profit sectors.

Conflict of interests: Corresponding author:

Open Access License:
Authors have declared that no competing interest exists.

Dr. Kostiantyn Prontenko, Department of Physical Education, Special Physical Training and Sport, S. P. Koroliov Zhytomyr Military Institute, Mira str., 22, 10001, Zhytomyr, Ukraine, tel.: +3-8-067-506-91-42, e-mail: prontenkokostya@ukr.net

This is an open access article distributed under the terms of the Creative Commons Attribution-Non-Commercial-NoDerivatives 4.0 International (https://creativecommons.org/licenses/by-nc-nd/4.0/), which permits use, distribution and reproduction in any medium, provided the original work is properly cited, the use is non-commercial and is otherwise in compliance with the license. 


\section{INTRODUCTION}

Nowadays kettlebell lifting is a common substantive sport which is actively developing in more than 50 world countries. It has its governing bodies international and national federations as well as a structure of competitions. It is characterized by physical and mental loads peculiar to such types of sport as skiing, rowing, cycling etc. [1-3]. The essence of kettlebell lifting is to lift kettlebells of definite weight as many times as you can in $10 \min [4,5,6]$. Modern competitions in kettlebell lifting include exercises with kettlebells weighed 24 and $32 \mathrm{~kg}$ according to the program of biathlon (jerk and snatch) and long cycle [7-9].

Scientists $[10,11]$ state that the main factor defining the structure of competitive activity focuses on achieving the highest result by a sportsman. The sports result which is a structure formatting factor of a competitive activity depends on two groups of components - providing and realization. In general, the components of competitive activity providing in any kind of sport is an sportsman's organism (body constitution, functional abilities of the main systems) and the components of realization are the levels of the technical, physical, and functional preparedness [12-14]. The specifics of kettlebell lifting (duration of performing exercises, weight of the kettlebells, weight categories, etc.) determine the main requirements for various components of athletes' preparedness [15-17]. Scientists [18-20] consider that the main tasks of preparedness in kettlebell lifting are improving the technique of exercises and providing the necessary level of physical qualities and functional abilities. No component is defined separately; every component depends on the level of improvement in the other components, and they are closely interconnected $[4,7,21]$. The analysis of literature [22-24] showed that the components of competitive activity providing in kettlebell lifting (model characteristics of physical, functional and technical preparedness of sportsmen) remain insufficiently substantiated.

The aim of the study is to ground the model characteristics of the main components of sportsmen' of different qualification preparedness in kettlebell lifting.

\section{MATERIAL AND METHODS}

\section{PARTICIPANTS}

In order to ground the model characteristics of the main components of sportsmen' preparedness (physical, functional and technical), we investigated the indicators of general and special physical qualities, functional abilities and main technical characteristics of kettlebell lifters of different qualification $(\mathrm{N}=77)$. Three groups were formed: group No. 1 - kettlebell lifters of a low qualification (the 3rd and the 2nd grades, $\mathrm{N}=34$ ); group No. 2 - kettlebell lifters who have the 1st grade and Candidate Masters of Sports (CMS) $(N=27)$; group No. 3 -sportsmen of a high qualification (Masters of Sports (MS) and Masters of Sports of International Level (MSIL), N=16). The investigation was conducted on the basis of the kettlebell lifting class of S. P. Koroliov Zhytomyr Military Institute in 2013-2019.

\section{METHODS}

The analysis of general physical preparedness was based on the following tests: $100 \mathrm{~m}$ race, pull-ups, $3 \mathrm{~km}$ race, push-ups on the bars, complex power exercise, complex agility exercise, standing long jumps, forward inclinations 
of body from a sitting position, crossing arms behind the back, holding an angle on parallel bars, holding the body in a horizontal position, hang on the crossbar, squats with a barbell on the shoulders, deadlift, bench press. The estimation of the special physical preparedness was based on the results of special preparation exercises: standing with two $32 \mathrm{~kg}$ kettlebells in the initial position, lifting two $32 \mathrm{~kg}$ kettlebells to the chest, half-squats with two $32 \mathrm{~kg}$ kettlebells, standing with two $24 \mathrm{~kg}$ kettlebells in the position of fixation, jumping out with $40 \mathrm{~kg}$ kettlebell in 2 minutes, deadlift $40 \mathrm{~kg}$ kettlebell in 2 minutes.

The investigation of the functional preparedness components was conducted through the following indicators: the heart rate at rest, systolic and diastolic blood pressure, vital capacity, respiratory muscles endurance, double product, timed inspiratory and expiratory capacities, heart rate recovery after a standard exercise (20 squats in $30 \mathrm{sec}$ ), physical working capacity through the PWC170 test (with the help of a cycloergometer), maximal oxygen consumption (MOC). The investigation of the indicators of functional preparedness was conducted in Zhytomyr Regional Medical Centre by medical staff in the first half of the day.

Testing of the technical preparedness characteristics was based on the following indicators:

- duration of the main phases of competitive exercises in kettlebell lifting: during jerk - the phase of holding kettlebells in the initial position before lifting, the working phase period (general duration of the phases of halfsquats, lifting, squatting, and standing up in the position of fixation), the phase of fixing kettlebells with straight arms above the head; during the long cycle - the phases of holding the kettlebells in the initial position before lowering and before lifting; during the snatch - the working phase period, the phase of fixation; general duration of the performance of a complete cycle of every competitive exercise (jerk, long cycle, snatch);

- power of supporting reaction in the main phases of exercises: during jerk and the long cycle - in the phase of lifting; during the snatch - in the phase of break;

- angular characteristics of the main phases of exercises: in the long cycle - an angle between the body and legs during lowering the kettlebells, between the body and legs (body and arms) at the «dead point», between the body and arms during lifting the kettlebells to the chest; during the snatch - an angle between the body and legs during lowering the kettlebell, between the body and legs (body and arm) at the «dead point», between the body and arm at the moment of break.

The investigation of the indicators of technical preparedness was held in the Laboratory of Biomechanics Technologies in Physical Education and Olympic Sport of the National University of Physical Education and Sport of Ukraine with the use of the opto-electronic system «Qualisys», eight-channel tenso platform and software «Qualisys Track Manager».

A set of modern general scientific methods was used to fulfill the aim of the research. They include theoretical analysis and generalization of scientific and methodological literature, pedagogic observation, testing, biomedical methods, video computer and biomechanical analysis, and methods of mathematical statistics. 


\section{STATISTICAL ANALYSES}

The methods of mathematical statistics were applied to correctly process the data and identify the difference between the studied indicators. The results were reported as Mean \pm SD. The authenticity of the difference between the sportsmen' of different qualification indicators was determined with the help of Student's t-test. The statistical significance for all statistical tests was set at $\mathrm{p}$ $<0.05$. All statistical analyses were performed with the SPSS software, version 21 , adapted to the medical and biological research.

\section{RESULTS}

The tasks of the kettlebell lifters' physical training are aimed at improving physical qualities, functional abilities of an organism, formation of capabilities to demonstrate physical qualities during the training process and competitive activity. These objectives are reached in the process of general and special physical training. The general physical training is performed in order to improve the health, working capacity, and the level of physical qualities. The main means of the general physical training involve running, sports games, exercises with sports equipment, etc. The high level of general physical preparedness is the basis for the special physical preparedness of kettlebell lifters. The special physical training is aimed at developing special physical qualities concerning the specifics of kettlebell lifting. The means of special physical training of kettlebell lifters are special preparing and competitive exercises. The results of the investigation of the physical preparedness of kettlebell lifters are shown in Table 1.

The analysis of the results in $100 \mathrm{~m}$ race showed that the level of speed qualities does not differ between the groups ( $p>0.05)$. The results in pull-ups, push-ups on the bars, complex power exercise are increased with improved qualification, but the authentic difference is determined just in the indicators of group № 1 and № 2 ( $\mathrm{p}<0.05$ ). The investigation of the results in $3 \mathrm{~km}$ race proves a high level of endurance development of kettlebell lifters of all groups. The highest level of endurance is determined in group № 3 - 11 min 20 sec. The best results in standing long jumps are defined in group № $2-246.9 \mathrm{~cm}$. The estimation of the indicators of flexibility and static endurance proves the authentic difference in the indicators of sportsmen from these groups ( $p<0.05-0.001$ ), which shows the connection of the efficiency of competitive $\square$ activity in kettlebell lifting and the development level of the mentioned physical qualities. The analysis of the results in power exercises with a barbell showed that the main load during performance of the exercises with the kettlebells is focused on the back and legs muscles.

The analysis of special physical preparedness showed that the sportsmen of a high qualification are defined to have the best results in all special preparation exercises (Table 1). It shows the necessity of a continuous improvement in the results of special preparation exercises during all stages of training in kettlebell lifting. 
Table 1. Model characteristics of physical preparedness of kettlebell lifters of different qualification $(\mathrm{N}=77$, Mean $\pm \mathrm{SD})$

\begin{tabular}{|c|c|c|c|c|c|c|}
\hline \multirow[b]{2}{*}{ Test } & \multicolumn{3}{|c|}{ The level of sports qualification } & \multicolumn{3}{|c|}{ Statistical significance } \\
\hline & $\begin{array}{c}\text { Group No. } \\
1 \text { (the } 3 r d \\
\text { and the } 2 \text { nd } \\
\text { grades, } n=34 \text { ) }\end{array}$ & $\begin{array}{c}\text { Group No. } 2 \\
\text { (the lst grade } \\
\text { and CMS, } \\
n=27 \text { ) }\end{array}$ & $\begin{array}{c}\text { Group No. } 3 \\
\text { (MS, MSIL, } \\
n=16)\end{array}$ & $p^{1}-p^{2}$ & $p^{2}-p^{3}$ & $p^{1}-p^{3}$ \\
\hline \multicolumn{7}{|c|}{ The indicators of general physical preparedness } \\
\hline $100 \mathrm{~m}$ race, sec & $13.98 \pm 0.09$ & $13.95 \pm 0.08$ & $14.02 \pm 0.10$ & $>0.05$ & $>0.05$ & $>0.05$ \\
\hline Pull-ups, reps & $18.5 \pm 0.87$ & $22.6 \pm 0.69$ & $23.2 \pm 0.71$ & $<0.001$ & $>0.05$ & $<0.001$ \\
\hline $3 \mathrm{~km}$ race, sec & $744.6 \pm 12.15$ & $709.2 \pm 9.87$ & $680.3 \pm 10.43$ & $<0.05$ & $<0.05$ & $<0.001$ \\
\hline $\begin{array}{l}\text { Push-ups on the bars, } \\
\text { reps }\end{array}$ & $31.7 \pm 2.23$ & $38.5 \pm 2.06$ & $39.9 \pm 1.95$ & $<0.05$ & $>0.05$ & $<0.05$ \\
\hline $\begin{array}{l}\text { Complex power } \\
\text { exercise, reps }\end{array}$ & $69.7 \pm 2.70$ & $78.8 \pm 2.45$ & $80.4 \pm 2.18$ & $<0.05$ & $>0.05$ & $<0.05$ \\
\hline $\begin{array}{l}\text { Complex agility } \\
\text { exercise, sec }\end{array}$ & $9.2 \pm 0.18$ & $8.5 \pm 0.21$ & $8.2 \pm 0.25$ & $<0.05$ & $>0.05$ & $<0.01$ \\
\hline $\begin{array}{l}\text { Standing long jumps, } \\
\mathrm{cm}\end{array}$ & $239.1 \pm 2.63$ & $246.9 \pm 2.77$ & $245.2 \pm 2.94$ & $<0.05$ & $>0.05$ & $>0.05$ \\
\hline $\begin{array}{l}\text { Forward inclinations of } \\
\text { body, } \mathrm{cm}\end{array}$ & $15.2 \pm 0.63$ & $17.1 \pm 0.69$ & $18.9 \pm 0.57$ & $<0.05$ & $<0.05$ & $<0.001$ \\
\hline $\begin{array}{l}\text { Crossing arms behind } \\
\text { the back, } \mathrm{cm}\end{array}$ & $2.4 \pm 0.49$ & $5.8 \pm 0.52$ & $8.7 \pm 0.61$ & $<0.001$ & $<0.001$ & $<0.001$ \\
\hline $\begin{array}{l}\text { Holding an angle on } \\
\text { bars, sec }\end{array}$ & $98.1 \pm 2.75$ & $116.4 \pm 2.90$ & $123.9 \pm 3.27$ & $<0.001$ & $>0.05$ & $<0.001$ \\
\hline $\begin{array}{l}\text { Holding the body in } \\
\text { a horizontal position, } \\
\text { sec }\end{array}$ & $207.2 \pm 4.96$ & $221.5 \pm 5.04$ & $238.0 \pm 5.54$ & $<0.05$ & $<0.05$ & $<0.001$ \\
\hline $\begin{array}{l}\text { Hang on the crossbar, } \\
\text { sec }\end{array}$ & $116.3 \pm 8.21$ & $177.9 \pm 8.47$ & $230.4 \pm 7.82$ & $<0.001$ & $<0.001$ & $<0.001$ \\
\hline $\begin{array}{l}\text { Squats with a barbell, } \\
\text { kg }\end{array}$ & $106.2 \pm 3.27$ & $117.1 \pm 3.58$ & $121.6 \pm 3.69$ & $<0.05$ & $>0.05$ & $<0.01$ \\
\hline Bench press, kg & $82.8 \pm 2.12$ & $86.4 \pm 2.30$ & $91.3 \pm 2.88$ & $>0.05$ & $>0.05$ & $>0.05$ \\
\hline Deadlift per, kg & $104.9 \pm 2.94$ & $118.6 \pm 3.07$ & $133.5 \pm 3.27$ & $<0.01$ & $<0.01$ & $<0.001$ \\
\hline \multicolumn{7}{|c|}{ The indicators of special physical preparedness } \\
\hline $\begin{array}{l}\text { Standing with two } 32 \\
\mathrm{~kg} \text { kettlebells in the } \\
\text { initial position, sec }\end{array}$ & $172.4 \pm 33.17$ & $425.1 \pm 25.24$ & $587.6 \pm 30.09$ & $<0.001$ & $<0.001$ & $<0.001$ \\
\hline $\begin{array}{l}\text { Lifting two } 32 \mathrm{~kg} \\
\text { kettlebells to the chest } \\
\text { in } 10 \mathrm{~min} \text {, reps }\end{array}$ & $26.5 \pm 2.91$ & $39.7 \pm 2.26$ & $69.8 \pm 3.18$ & $<0.01$ & $<0.001$ & $<0.001$ \\
\hline $\begin{array}{l}\text { Half-squats with two } \\
32 \mathrm{~kg} \text { kettlebells, reps }\end{array}$ & $67.4 \pm 9.68$ & $185.3 \pm 28.45$ & $356.2 \pm 37.40$ & $<0.001$ & $<0.01$ & $<0.001$ \\
\hline $\begin{array}{l}\text { Standing with two } 24 \\
\text { kg kettlebells in the } \\
\text { position of fixation, } \\
\text { sec }\end{array}$ & $22.5 \pm 2.76$ & $44.8 \pm 2.17$ & $76.2 \pm 3.50$ & $<0.001$ & $<0.001$ & $<0.001$ \\
\hline $\begin{array}{l}\text { Jumping out with } 40 \\
\text { kg kettlebell in } 2 \text { min, } \\
\text { reps }\end{array}$ & $49.7 \pm 2.04$ & $64.5 \pm 1.97$ & $82.1 \pm 2.35$ & $<0.001$ & $<0.001$ & $<0.001$ \\
\hline $\begin{array}{l}\text { Deadlift } 40 \mathrm{~kg} \\
\text { kettlebell in } 2 \mathrm{~min} \text {, } \\
\text { reps }\end{array}$ & $58.3 \pm 2.19$ & $66.1 \pm 2.05$ & $74.8 \pm 2.49$ & $<0.05$ & $<0.05$ & $<0.001$ \\
\hline
\end{tabular}

Legend: N - number of subjects; Mean - arithmetical average; SD - standard deviation; $\mathrm{p}^{1}-\mathrm{p}^{2}$ - significance of difference between group No. 1 and group No. 2 sportsmen's indicators; $\mathrm{p}^{2}-\mathrm{p}^{3}-$ significance of difference between group No. 2 and group No. 3 sportsmen's indicators; $\mathrm{p}^{1}-\mathrm{p}^{3}$ - significance of difference between group No. 1 and group No. 3 sportsmen's indicators. 
It should be mentioned that there are weight categories in kettlebell lifting. This factor should be considered while applying differential approaches to the development of athletes' physical qualities. That is why we conducted an analysis of the power indicators dynamics through the following tests: squats, bench press, and deadlift (Table 2). The sportsmen were divided into 4 subgroups of weight categories: 63-68 kg; 73-78 kg; $85 \mathrm{~kg}$; 95 - over $95 \mathrm{~kg}$. The investigation of the results in power exercises shows that the indicators of muscles strength improve with the increased qualification in the subgroups of light and medium weight categories (63-68 kg and 73-78 kg) $(\mathrm{p}<0.05-0.001)$; the results improve with the increased qualification in the weight category $85 \mathrm{~kg}$; however, the difference in the indicators of the sportsmen of groups No. 3 and 2 is not significant ( $p>0.05$ ). The sportsmen of group No. 2 of the weight category 95 - over $95 \mathrm{~kg}$ are determined to have the highest results in squats. Therefore, the analysis of the results in power exercises proved the continuous improvement of power qualities with the increased qualification in groups No. 1 and 2 and no authentic increase in group No. 3. Additionally, the authentic improvement with the increased qualification is seen in light and medium weight categories $(\mathrm{p}<0.05)$, and the results of sportsmen of the weight category 95 - over $95 \mathrm{~kg}$ of different qualification do not significantly differ ( $p$ > 0.05). It states the importance of developing power qualities of the sportsmen of 63-78 kg weight categories in order to provide the efficient $\square$ competitive activity, but the necessity to improve power qualities decreases in the categories of $85 \mathrm{~kg}$ and higher.

Table 2. Model characteristics of power qualities of kettlebell lifters of different qualification concerning weight categories $(\mathrm{N}=77$, Mean $\pm \mathrm{SD}, \mathrm{kg})$

\begin{tabular}{|c|c|c|c|c|c|c|c|}
\hline \multirow[b]{2}{*}{$\begin{array}{c}\text { The level of sports } \\
\text { qualification }\end{array}$} & \multicolumn{4}{|c|}{ Subgroups of weight categories } & \multicolumn{3}{|c|}{ Confidence intervals } \\
\hline & $\begin{array}{c}\text { Subgroup } \\
163-68 \mathrm{~kg} \\
(n=20)\end{array}$ & $\begin{array}{l}\text { Subgroup } \\
273-78 \mathrm{~kg} \\
(\mathrm{n}=22)\end{array}$ & $\begin{array}{c}\text { Subgroup } \\
385 \mathrm{~kg} \\
(\mathrm{n}=18)\end{array}$ & $\begin{array}{c}\text { Subgroup } 4 \\
95 \text { - over } 95 \\
\text { kg }(n=17)\end{array}$ & $p^{1}-p^{2}$ & $p^{2}-p^{3}$ & $p^{1}-p^{3}$ \\
\hline \multicolumn{8}{|c|}{ Squats with a barbell on the shoulders } \\
\hline $\begin{array}{l}\text { Group No. } 1 \text { (the } 3 \text { rd, } \\
\text { the } 2 \text { nd grades) }\end{array}$ & $92.5 \pm 3.17$ & $98.4 \pm 4.12$ & $106.8 \pm 3.78$ & $119.2 \pm 4.73$ & $>0.05$ & $>0.05$ & $<0.05$ \\
\hline $\begin{array}{l}\text { Group No. } 2 \text { (the 1st } \\
\text { grade, CMS) }\end{array}$ & $99.8 \pm 4.28$ & $112.7 \pm 4.57$ & $119.5 \pm 4.61$ & $127.3 \pm 4.92$ & $<0.05$ & $>0.05$ & $>0.05$ \\
\hline $\begin{array}{l}\text { Group No. } 3 \text { (MS, } \\
\text { MSIL) }\end{array}$ & $113.3 \pm 5.83$ & $120.5 \pm 4.93$ & $125.9 \pm 6.24$ & $126.6 \pm 6.77$ & $>0.05$ & $>0.05$ & $>0.05$ \\
\hline$p^{1}-p^{2}$ & $>0.05$ & $<0.05$ & $<0.05$ & $>0.05$ & & & \\
\hline$p^{2}-p^{3}$ & $>0.05$ & $>0.05$ & $>0.05$ & $>0.05$ & & & \\
\hline$p^{1}-p^{3}$ & $<0.01$ & $<0.01$ & $<0.05$ & $>0.05$ & & & \\
\hline \multicolumn{8}{|c|}{ Bench press } \\
\hline $\begin{array}{l}\text { Group No. } 1 \text { (the } 3 \text { rd, } \\
\text { the } 2 \text { nd grades) }\end{array}$ & $65.7 \pm 3.84$ & $72.4 \pm 3.96$ & $81.9 \pm 5.11$ & $92.6 \pm 4.50$ & $>0.05$ & $>0.05$ & $>0.05$ \\
\hline $\begin{array}{l}\text { Group No. } 2 \text { (the 1st } \\
\text { grade, CMS) }\end{array}$ & $75.5 \pm 4.36$ & $82.6 \pm 4.12$ & $90.7 \pm 4.84$ & $96.8 \pm 4.88$ & $>0.05$ & $>0.05$ & $>0.05$ \\
\hline $\begin{array}{l}\text { Group No. } 3 \text { (MS, } \\
\text { MSIL) }\end{array}$ & $80.4 \pm 5.92$ & $88.7 \pm 4.47$ & $92.8 \pm 6.08$ & $95.9 \pm 7.12$ & $>0.05$ & $>0.05$ & $>0.05$ \\
\hline$p^{1}-p^{2}$ & $>0.05$ & $>0.05$ & $>0.05$ & $>0.05$ & & & \\
\hline$p^{2}-p^{3}$ & $>0.05$ & $>0.05$ & $>0.05$ & $>0.05$ & & & \\
\hline$p^{1}-p^{3}$ & $<0.05$ & $<0.05$ & $>0.05$ & $>0.05$ & & & \\
\hline
\end{tabular}


Baltic Journal of Health and Physical Activity 2020; 12 (3): 92-102

Journal of Gdansk University of Physical Education and Sport

e-ISSN 2080-9999

\begin{tabular}{|c|c|c|c|c|c|c|c|}
\hline \multirow[b]{2}{*}{$\begin{array}{c}\text { The level of sports } \\
\text { qualification }\end{array}$} & \multicolumn{4}{|c|}{ Subgroups of weight categories } & \multicolumn{3}{|c|}{ Confidence intervals } \\
\hline & $\begin{array}{c}\text { Subgroup } \\
163-68 \mathrm{~kg} \\
(\mathrm{n}=20)\end{array}$ & $\begin{array}{l}\text { Subgroup } \\
273-78 \mathrm{~kg} \\
(n=22)\end{array}$ & $\begin{array}{c}\text { Subgroup } \\
385 \mathrm{~kg} \\
(\mathrm{n}=18)\end{array}$ & $\begin{array}{c}\text { Subgroup } 4 \\
95 \text { - over } 95 \\
\text { kg }(n=17)\end{array}$ & $p^{1}-p^{2}$ & $p^{2}-p^{3}$ & $p^{1}-p^{3}$ \\
\hline \multicolumn{8}{|c|}{ Deadlift } \\
\hline $\begin{array}{l}\text { Group No. } 1 \text { (the } 3 r d \text {, } \\
\text { the } 2 \text { nd grades) }\end{array}$ & $90.7 \pm 3.96$ & $99.8 \pm 3.25$ & $110.4 \pm 4.78$ & $121.8 \pm 4.88$ & $>0.05$ & $>0.05$ & $>0.05$ \\
\hline $\begin{array}{l}\text { Group No. } 2 \text { (the 1st } \\
\text { grade, CMS) }\end{array}$ & $107.6 \pm 4.15$ & $114.5 \pm 3.81$ & $125.6 \pm 4.58$ & $133.8 \pm 5.06$ & $>0.05$ & $>0.05$ & $>0.05$ \\
\hline $\begin{array}{l}\text { Group No. } 3 \text { (MS, } \\
\text { MSIL) }\end{array}$ & $120.1 \pm 4.67$ & $128.3 \pm 4.54$ & $136.3 \pm 5.86$ & $142.2 \pm 6.19$ & $>0.05$ & $>0.05$ & $>0.05$ \\
\hline$p^{1}-p^{2}$ & $<0.01$ & $<0.01$ & $<0.05$ & $>0.05$ & & & \\
\hline$p^{2}-p^{3}$ & $<0.05$ & $<0.05$ & $>0.05$ & $>0.05$ & & & \\
\hline$p^{1}-p^{3}$ & $<0.001$ & $<0.001$ & $<0.01$ & $<0.05$ & & & \\
\hline
\end{tabular}

Legend: $\mathrm{n}$ - number of subjects; Mean - arithmetical average; SD - standard deviation; $\mathrm{p}^{1}-\mathrm{p}^{2}$ - significance of difference between subgroup 1 and subgroup 2 sportsmen's indicators; p2-p3 - significance of difference between subgroup 2 and subgroup 3 sportsmen's indicators; $\mathrm{p}^{3}-\mathrm{p}^{4}-$ significance of difference between subgroup 3 and subgroup 4 sportsmen's indicators; $\mathrm{p}^{1}-\mathrm{p}^{2}$ - significance of difference between group No. 1 and group No. 2 sportsmen's indicators; $\mathrm{p}^{2}-\mathrm{p}^{3}$ - significance of difference between group No. 2 and group No. 3 sportsmen's indicators; $p^{1}-p^{3}-$ significance of difference between group No. 1 and group No. 3 sportsmen's indicators.

The analysis of sportsmen's functional preparedness (Table 3) shows that indicators improve with increased qualification, and the highest level is defined in group No. 3. Such indicators of the cardiovascular system as the heart rate, blood pressure, double product and heart rate recovery of sportsmen from group No. 3 are the best. The indicators of the respiratory system are the highest and prove a high level of the functional state of the kettlebell lifters of a high qualification. The level of physical capacity and MOC of kettlebell lifters of a high qualification equals the indicators of the representatives of cyclic sports developing endurance (track and field athletics, skiing, cycling, etc.). It shows a high level of endurance and wide functional abilities of the highly-qualified kettlebell lifters' organisms.

Table 3. Model characteristics of functional preparedness of kettlebell lifters of different qualification $(\mathrm{N}=77$, Mean $\pm \mathrm{SD})$

\begin{tabular}{|c|c|c|c|c|c|c|}
\hline \multirow[b]{2}{*}{$\begin{array}{l}\text { The indicators of } \\
\text { functional preparedness }\end{array}$} & \multicolumn{3}{|c|}{ The level of sports qualification } & \multicolumn{3}{|c|}{ Statistical significance } \\
\hline & $\begin{array}{l}\text { Group No. } \\
1 \text { (the } 3 r d \\
\text { and the } 2 \text { nd } \\
\text { grades, } n=34 \text { ) }\end{array}$ & $\begin{array}{c}\text { Group No. } 2 \\
\text { (the 1st grade } \\
\text { and CMS, } \\
n=27 \text { ) }\end{array}$ & $\begin{array}{c}\text { Group No. } 3 \\
\text { (MS, MSIL, } \\
n=16)\end{array}$ & $p^{1}-p^{2}$ & $p^{2}-p^{3}$ & $p^{1}-p^{3}$ \\
\hline Heart rate at rest, beats/min & $71.2 \pm 0.72$ & $68.7 \pm 0.79$ & $61.9 \pm 1.09$ & $<0.05$ & $<0.001$ & $<0.001$ \\
\hline Systolic blood pressure, $\mathrm{mmHg}$ & $123.8 \pm 1.03$ & $119.2 \pm 1.06$ & $116.1 \pm 1.12$ & $<0.01$ & $<0.05$ & $<0.001$ \\
\hline Diastolic blood pressure, $\mathrm{mmHg}$ & $72.8 \pm 0.92$ & $70.7 \pm 0.89$ & $68.2 \pm 0.80$ & $>0.05$ & $<0.05$ & $<0.01$ \\
\hline Vital capacity, ml & $4060.7 \pm 79.25$ & $4485.5 \pm 71.42$ & $4897.2 \pm 113.5$ & $<0.01$ & $<0.01$ & $<0.001$ \\
\hline $\begin{array}{l}\text { Respiratory muscles } \\
\text { endurance, } \mathrm{ml}\end{array}$ & $3912.3 \pm 84.22$ & $4407.2 \pm 75.39$ & $4915.3 \pm 115.6$ & $<0.001$ & $<0.01$ & $<0.001$ \\
\hline Double product, s.u. & $88.3 \pm 1.95$ & $81.9 \pm 2.09$ & $72.6 \pm 1.74$ & $<0.05$ & $<0.01$ & $<0.001$ \\
\hline Timed inspiratory capacity, sec & $64.7 \pm 3.20$ & $80.8 \pm 3.92$ & $96.5 \pm 3.66$ & $<0.01$ & $<0.05$ & $<0.001$ \\
\hline Timed expiratory capacity, sec & $39.8 \pm 1.64$ & $46.9 \pm 1.58$ & $57.1 \pm 1.76$ & $<0.01$ & $<0.001$ & $<0.001$ \\
\hline Heart rate recovery, sec & $115.7 \pm 3.57$ & $98.2 \pm 3.88$ & $79.4 \pm 3.25$ & $<0.01$ & $<0.01$ & $<0.001$ \\
\hline 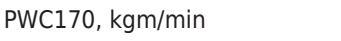 & $1094.3 \pm 59.71$ & $1298.7 \pm 62.52$ & $1476.6 \pm 56.80$ & $<0.05$ & $<0.05$ & $<0.001$ \\
\hline $\mathrm{PWC170} / \mathrm{kg}, \mathrm{kgm} / \mathrm{min} / \mathrm{kg}$ & $15.3 \pm 0.91$ & $17.9 \pm 0.86$ & $21.1 \pm 1.03$ & $<0.05$ & $<0.05$ & $<0.001$ \\
\hline $\mathrm{MOC}, \mathrm{ml} / \mathrm{min}$ & $3477.4 \pm 76.54$ & $3920.5 \pm 69.83$ & $4318.5 \pm 79.76$ & $<0.01$ & $<0.01$ & $<0.001$ \\
\hline $\mathrm{MOC} / \mathrm{kg}, \mathrm{ml} / \mathrm{min} / \mathrm{kg}$ & $48.6 \pm 1.53$ & $53.7 \pm 1.47$ & $62.3 \pm 1.60$ & $<0.05$ & $<0.01$ & $<0.001$ \\
\hline
\end{tabular}

Legend: $\mathrm{N}$ - number of subjects; Mean - arithmetical average; SD - standard deviation; $\mathrm{p}^{1}-\mathrm{p}^{2}$ - significance of difference between group No. 1 and group No. 2 sportsmen's indicators; $\mathrm{p}^{2}-\mathrm{p}^{3}$ - significance of difference between group No. 2 and group No. 3 sportsmen's indicators; $\mathrm{p}^{1}-\mathrm{p}^{3}$ - significance of difference between group No. 1 and group No. 3 sportsmen's indicators. 
The main tasks of technical training involve mastering the necessary skills and abilities, improving the technique by changing its dynamic and kinematic parameters, ensuring the variation of the equipment and its adequacy to the conditions of competitive activity, ensuring the resistance of the main characteristics of the technique to the action of «knocking down» factors. The technique is characterized by kinematic (the position of the body and parts of the body, the trajectory of their movement, the duration of the actions), dynamic (impulse, power of supporting reaction, etc.) and rhythmic (rhythm as an integral parameter) characteristics. Depending on physiological peculiarities, the level of development of physical qualities and the technique may be different, because they are individual. The low level of the development of physical qualities may worsen the rational technique. Highly-qualified kettlebell lifters are distinguished from low skilled sportsmen by their ability to quickly relax muscles during exercise, even in the last minutes regardless of considerable exhaustion that shows a high level of technical preparedness. The most important element of sports technique is the rational rhythm of an exercise which is characterized by a certain ratio of the time of implementation of individual phases of the exercise. Accentuated effort during the main phase of an exercise is a characteristic feature of the correct rhythm. Kettlebell lifters' ability to work at the same pace for 6-8 minutes and accelerate in the last minute of the competition section (9-10 msn) indicates the perfection of technique. The results of the study of sportsmen's technical preparedness are shown in Table 4.

The analysis of the duration of the main phases showed that it takes the sportsmen of a high qualification much less time to recover in the phase of holding the kettlebells before lifting. Due to this, the duration of a cycle is reduced, the pace of exercise is increased and the result in exercise is improved. The analysis of the power of supporting reaction dynamics during all phases of the snatch, static phases of the jerk and the long cycle showed no significant difference in the sportsmen's indicators $(p>0.05)$. The significant difference in the power of supporting reaction indicators for all weight categories is determined in the phases of lifting in the jerk and the long cycle $(p<0.05-0.001)$. The analysis of angular characteristics between the body and legs, the body and arms at the moment of lifting the kettlebells and also when the kettlebells are in the extreme back position behind the knees during lowering («dead point») proves that sportsmen of a low qualification perform incorrect forward inclination of the body. This puts big pressure on the muscles of the back and arms (forearms, hands) and leads to premature exhaustion and decreased results. Therefore, the investigation of angles between the parts of body during the main phases of competitive exercises showed that the kettlebell lifters of a high qualification have authentically better results of technical preparedness $(p<0.001)$ than the kettlebell lifters of a low qualification. 
Table 4. Model characteristics of technical preparedness of kettlebell lifters of different qualification $(\mathrm{N}=77$, Mean $\pm \mathrm{SD})$

\begin{tabular}{|c|c|c|c|c|c|c|}
\hline \multirow[b]{2}{*}{$\begin{array}{c}\text { The indicators of technical } \\
\text { preparedness }\end{array}$} & \multicolumn{3}{|c|}{ The level of sports qualification } & \multicolumn{3}{|c|}{ Statistical significance } \\
\hline & $\begin{array}{c}\text { Group No. } \\
1 \text { (the 3rd } \\
\text { and the } 2 n d \\
\text { grades, } n=34 \text { ) }\end{array}$ & $\begin{array}{l}\text { Group No. } \\
2 \text { (the } 1 \text { st } \\
\text { grade and } \\
\text { CMS, } n=27 \text { ) }\end{array}$ & $\begin{array}{c}\text { Group No. } 3 \\
\text { (MS, MSIL } \\
n=16)\end{array}$ & $p^{1}-p^{2}$ & $p^{2}-p^{3}$ & $p^{1}-p^{3}$ \\
\hline \multicolumn{7}{|c|}{ Duration of the main phases of the competitive exercises performance, sec } \\
\hline $\begin{array}{l}\text { An initial position before lifting } \\
\text { the kettlebells in jerk }\end{array}$ & $7.18 \pm 0.38$ & $4.61 \pm 0.41$ & $2.13 \pm 0.27$ & $<0.001$ & $<0.001$ & $<0.001$ \\
\hline Working period in jerk & $3.59 \pm 0.36$ & $2.87 \pm 0.31$ & $2.05 \pm 0.25$ & $>0.05$ & $<0.05$ & $<0.01$ \\
\hline Fixation in jerk & $1.03 \pm 0.12$ & $0.98 \pm 0.09$ & $1.37 \pm 0.13$ & $>0.05$ & $<0.05$ & $>0.05$ \\
\hline $\begin{array}{l}\text { An initial position before } \\
\text { lowering the kettlebells in a } \\
\text { long cycle }\end{array}$ & $5.04 \pm 0.31$ & $3.27 \pm 0.49$ & $1.65 \pm 0.31$ & $<0.01$ & $<0.01$ & $<0.001$ \\
\hline $\begin{array}{l}\text { An initial position before lifting } \\
\text { the kettlebells in a long cycle }\end{array}$ & $9.87 \pm 0.57$ & $7.36 \pm 0.52$ & $4.89 \pm 0.35$ & $<0.01$ & $<0.01$ & $<0.001$ \\
\hline Working period in snatch & $2.84 \pm 0.38$ & $3.35 \pm 0.35$ & $2.69 \pm 0.32$ & $>0.05$ & $>0.05$ & $>0.05$ \\
\hline Fixation in snatch & $1.45 \pm 0.17$ & $1.06 \pm 0.14$ & $1.24 \pm 0.13$ & $>0.05$ & $>0.05$ & $>0.05$ \\
\hline Duration of one cycle in jerk & $14.32 \pm 0.61$ & $9.79 \pm 0.56$ & $6.21 \pm 0.30$ & $<0.001$ & $<0.001$ & $<0.001$ \\
\hline $\begin{array}{l}\text { Duration of one cycle in a long } \\
\text { cycle }\end{array}$ & $24.76 \pm 0.59$ & $16.55 \pm 0.46$ & $10.02 \pm 0.34$ & $<0.001$ & $<0.001$ & $<0.001$ \\
\hline Duration of one cycle in snatch & $4.29 \pm 0.18$ & $4.43 \pm 0.15$ & $3.94 \pm 0.09$ & $>0.05$ & $>0.05$ & $>0.05$ \\
\hline
\end{tabular}

Angular characteristics of the main phases of competitive exercises, degrees

An angle between the body and arms during lowering the kettlebells in a long cycle

An angle between the body and legs at the «dead point» in a long cycle

An angle between the body and arms at the «dead point» in a long cycle

An angle between the body and arms during lifting the kettlebells in a long cycle

An angle between the body and arm during lowering the kettlebell in snatch

An angle between the body and legs at the «dead point» in snatch

An angle between the body and arm at the «dead point» in snatch

An angle between the body and arm at the moment of break in snatch

\begin{tabular}{|c|c|c|c|c|c|}
\hline $26.2 \pm 0.98$ & $19.8 \pm 0.87$ & $8.1 \pm 0.39$ & $<0.001$ & $<0.001$ & $<0.001$ \\
\hline $107.8 \pm 1.05$ & $94.1 \pm 0.91$ & $86.5 \pm 1.24$ & $<0.001$ & $<0.001$ & $<0.001$ \\
\hline $36.2 \pm 1.37$ & $25.6 \pm 1.28$ & $17.9 \pm 1.02$ & $<0.001$ & $<0.001$ & $<0.001$ \\
\hline $28.5 \pm 0.71$ & $13.1 \pm 0.62$ & $4.3 \pm 0.47$ & $<0.001$ & $<0.001$ & $<0.001$ \\
\hline $23.1 \pm 0.91$ & $18.4 \pm 0.93$ & $7.2 \pm 0.45$ & $<0.01$ & $<0.001$ & $<0.001$ \\
\hline $112.9 \pm 1.26$ & $104.5 \pm 0.98$ & $90.3 \pm 1.09$ & $<0.001$ & $<0.001$ & $<0.001$ \\
\hline $41.5 \pm 1.15$ & $13.6 \pm 1.21$ & $12.4 \pm 0.96$ & $<0.001$ & $<0.001$ & $<0.001$ \\
\hline $7.3 \pm 0.66$ & $10.7 \pm 0.59$ & $3.9 \pm 0.41$ & $<0.001$ & $<0.001$ & $<0.001$ \\
\hline
\end{tabular}

Legend: $\mathrm{N}$ - number of subjects; Mean - arithmetical average; SD - standard deviation; $\mathrm{p}^{1}-\mathrm{p}^{2}$ - significance of difference between group No. 1 and group No. 2 sportsmen's indicators; $\mathrm{p}^{2}-\mathrm{p}^{3}$ - significance of difference between group No. 2 and group No. 3 sportsmen's indicators; $\mathrm{p}^{1}-\mathrm{p}^{3}$ - significance of difference between group No. 1 and group No. 3 sportsmen's indicators.

\section{DISCUSSION}

The analysis of general physical preparedness showed that the level of physical qualities development differs depending on the athletes' qualification. Therefore, to increase the efficiency of the training process, the development $\square$ of general endurance, flexibility, static body and arms muscles endurance and power qualities acquire paramount importance. The investigation of the dynamics of power indicators proves the importance of the development of 
the dynamics of power indicators proves the importance of the development of back and legs muscles power in sportsmen of the $63-78 \mathrm{~kg}$ weight category in order to ensure the efficiency of their training and competitive processes, $\square$ and the necessity of the power qualities improvement is decreased for the sportsmen of the weight category of $85 \mathrm{~kg}$ and higher. The analysis of the indicators of special physical preparedness states that special preparation exercises are crucial for the high results in kettlebell lifting. The investigation of the functional preparedness indicators proves that in order to achieve high results in kettlebell lifting there are considerably high requirements for the development of endurance. It is determined that functional abilities of the cardiorespiratory system are informally meaningful indicators of kettlebell lifters' functional preparedness. According to the results of the investigation of the technical preparedness, it is defined that the kettlebell lifters of a high qualification have authentically better results in the duration of the main phases of competitive exercises (less duration), static phases, working period and one complete cycle of exercises. The reduction of these phases is an important task in training the process. The analysis of the power of supporting reaction shows that the technique of the main phases of the jerk and long cycle of the sportsmen of a high qualification is more economical and rational. The investigation of angles between the parts of body during the main phases of long cycle and snatch showed that highly-qualified kettlebell lifters have significantly better indicators of technical preparedness. The results of our study confirm and supplement the conclusions of many scientists [1, 3, 5, 6-9, 15, 25-28]. The prospects for further research are aimed at studying the problem of formation of psychological readiness of sportsmen to competitions in kettlebell lifting.

\section{CONCLUSIONS}

The results of the conducted investigation determine that the meaningful components of general physical preparedness for achieving high results in kettlebell lifting include endurance, flexibility, leg and back muscles strength; of special physical preparedness - the results in the main special preparation exercises; of functional preparedness - functional abilities of the cardiovascular and respiratory systems; of technical preparedness - duration of the static phases in competitive exercises, power of supporting reaction and angular characteristics of the main phases of exercises. The results of the investigation approve many scientists' conclusions that the models of preparedness allow revealing the reserves of the planned indicators of competitive activity achievement, to determine the main directions of improving preparedness, to define the optimal levels of developing its different aspects and their correlations. The application of models allows comparing the individual data of a particular sportsman with the model characteristics of highly-qualified sportsmen, to estimate the advantages and disadvantages of his preparedness, to plan and adjust the training process, and to select the means and methods of influence.

\section{REFERENCES}

[1] Beauchamp R, Pike S. The kettlebell bible. UK: Bear Publishing; 2006.

[2] Lake J, Lauder MA. Kettlebell swing training improves maximal and explosive strength. J Strength Condition Res. 2012;26(8):2228-2233. https://doi.org/10.1519/JSC.0b013e31825c2c9b

[3] Williams BM, Kraemer RR. Comparison of cardiorespiratory and metabolic responses in kettlebell high-intensity interval training versus sprint interval cycling. J Strength Condition Res. 2015;29 (12):3317-3325. https://doi.org/10.1519/JSC.0000000000001193

[4] Tsatsouline P. Enter the kettlebell. St. Paul, MN: Dragon Door Publications; 2006.

[5] Kuzmin AA. Kettlebell sport: Iron sport for iron men. Methods of training by Andrey Kuzmin. Ohio; 2003. 
[6] Prontenko K, Andreychuk V, Martin V et al. Improvement of physical preparedness of sportsmen in kettlebell sport on the stage of the specialized base preparation. Journal of Physical Education and Sport. 2016;16(2):540-545. https://doi.org/10.7752/jpes.2016.02085

[7] Vatel S, Gray VD. Kettlebells: Strength training for power and grace. New York: Sterling Publishing; 2005.

[8] Prontenko K, Griban G, Tymoshenko O et al. Methodical system of kettlebell lifting training of cadets during their physical education. International Journal of Applied Exercise Physiology. 2019;8(3.1):240248. https://doi.org/10.30472/ijaep.v8i3.1.656

[9] Prontenko K, Griban G, Prontenko V et al. Level and dynamics of functional preparedness indexes of kettlebell sportsmen. J Phys Educn Sport. 2017;17(2):712-716. https://doi.org/10.7752/jpes.2017.02107

[10] Platonov VN. Periodizatsiya sportivnoy trenirovki. Obschaya teoriya i ee prakticheskoe primenenie [Periodization of sports training. General theory and its practical application]. Kiev: Olimpiyskaya literatura; 2014. Russian.

[11] De Castro FMP, Aquino R, Berti Junior JA, Goncalves LGC, Puggina EF. Strength training with vascular occlusion: A review of possible adaptive mechanisms. Human Mov. 2017;18(2):3-14. https://doi. org/10.1515/humo-2017-0010

[12] Farrar RE, Mayhew JL, Koch AJ. Oxygen cost of kettlebell swings. J Strength Condition Res. 2010;24(4):1034-1036. https://doi.org/10.1519/JSC.0b013e3181d15516

[13] Manocchia P, Spierer DK, Lufkin AK, Minichiello J, Castro J. Transference of kettlebell training to strength, power, and endurance. J Strength Condition Res. 2013;27(2);477-484. https://doi. org/10.1519/JSC.0b013e31825770fe

[14] Jay K, Frisch D, Hansen K et al. Kettlebell training for musculoskeletal and cardiovascular health: A randomized controlled trial. Scand J Work Environ Health. 2011;37(3):196-203. https://doi. org/10.5271/sjweh.3136

[15] Fable S. Kettlebell comeback. IDEA Fitness J.2010;7(2):25-27.

[16] Thomas JF, Larson KL, Hollander DB, Kraemer PR. Comparison of two-hand kettlebell exercise and graded treadmill walking: effectiveness as a stimulus for cardiorespiratory fitness. J Strength Condition Res. 2014;28(4):998-1006. https://doi.org/10.1519/JSC.0000000000000345

[17] Bolotin A, Bakayev V, Vazhenin S. Pedagogical model for developing skills required by cadets of higher education institutions of the Aerospace Forces to organize their kettlebell self-training. J Phys Educ Sport. 2016;6(1):177-186. https://doi.org/10.1519/JSC.0000000000000345

[18] Ho-Jin J, Yong-Seong K, Woon-Soo C, Won-Gi K, Yong-Beom K, Yong-Nam K. Effect of kettlebell swing exercise on the body composition and lower limb muscular activity. J Korean Phys Ther. 2017;29 (4):194-200. https://doi.org/10.18857/jkpt.2017.29.4.194

[19] Hulsey CR, Soto DT, Koch AJ, Mayhew JL. Comparison of kettlebell swings and treadmill running at equivalent rating of perceived exertion values. J Strength Condition Res. 2012;26:1203-1207. https:// doi.org/10.1519/JSC.0b013e3182510629

[20] McGill SM, Marshall LW. Kettlebell swing, snatch, and bottoms-up carry: Back and hip muscle activation, motion, and low back loads. J Strength Condition Res. 2012;26 (1):16-27. https://doi. org/10.1519/JSC.0b013e31823a4063

[21] Brumitt J, Gilpin HE, Brunette M, Meira EP. Incorporating kettlebells into a lower extremity sports rehabilitation program. North Am J Sport Phys Ther. 2010;5:257-265.

[22] Ambrozy T, Kiszczak L, Omorczyk J, et al. Influence of experimental training with external resistance in a form of «kettlebell» on selected components of women's physical fitness. Balt J Health Phys Activ. 2017;9(1):28-36. doi: 10.29359/BJHPA.09.1.03

[23] Maulit MR, Archer DC, Leyva WhD, et al. Effects of kettlebell swing vs. explosive deadlift training on strength and power. Int J Kinesiol Sport Sci. 2017;5 (1):1-7. https://doi.org/10.7575//aiac.ijkss.v.5n.1p.1

[24] Kruszewski M, Kruszewski A, Kuzmicki S, et al. The effectiveness of kettlebell exercises in the aspects of special efficiency training in American football .Balt J Health Phys Activ. 2017;9(3):53-62. https:// doi.org/10.29359/BJHPA.09.3.05

[25] Prontenko K, Klachko V, Bondarenko V, et al. Technical preparedness of sportsmen in the kettlebell sport. J Phys Educ Sport. 2017;17 (Suppl. issue 1):28-33. https://doi.org/10.7752/jpes.2017.s1005

[26] Prontenko K, Griban G, Bloshchynskyi I, et al. Development of power qualities of cadets of Ukrainian higher military educational institutions during kettlebell lifting training. Balt J Health Phys Activ. 2019;11(3):27-38. https://doi.org/10.29359/BJHPA.11.3.04

[27] Prontenko K, Griban G, Aloshyna A, et al. Analysis of cadets' endurance development at higher military educational institutions during the kettlebell lifting training. Sport Mont. 2019;17 (2):3-8. https://doi.org/10.26773/smj.190601

[28] Prontenko K, Griban G, Yavorska T, et al. Dynamics of respiratory system indices of cadets of higher military educational institutions during kettlebell lifting training. Int J Appl Exerc Physiol. 2020;9 (1):16-24. [Available at http://www.ijaep.com/index.php/IJAE/article/view/707] [Accessed on 20 January, 2020]. 